\title{
Japanese face stiff barriers in recycling of nuclear fuel
}

Tokyo. A proposal by Japan's leading nuclear power organization to recycle nuclear fuel to reduce the possibility of plutonium being diverted to nuclear weapons (see $\mathrm{Na}$ ture 359,$663 ; 1992$ ), is an old idea that faces formidable economic and technical barriers. But Japan's commitment to use plutonium regardless of cost (see story at right) may bring it within reach.

The idea is to incorporate into reprocessed plutonium fuel those radioactive transuranic elements, such as americium, neptunium and curium, normally discarded as high-level radioactive waste. The president of the Power Reactor and Nuclear Fuel Development Corporation (PNC), a semigovernment organization affiliated with the Science and Technology Agency, hinted at the proposal at a symposium in Tokyo earlier this month, and his comments were fleshed out last week by PNC officials.

The approach would make it much more difficult to divert the plutonium to the manufacture of nuclear weapons. Weapons require fairly pure plutonium (ideally only the plutonium isotope 239), an alpha-particle emitter that can be handled in glove boxes and encased in a light shell. But americium 241 , the dominant isotope of americium in high-level liquid waste, emits gamma as well as alpha radiation and can be handled only with manipulators in 'hot cells' that have concrete walls several metres thick. Thus, plutonium contaminated with americium is not suitable for making bombs.

John Nedderman, a British nuclear power consultant in Tokyo, says that the PNC proposal is a throwback to the idea of "dirty" reprocessing proposed by US President Jimmy Carter as a way of discouraging the highjacking of nuclear fuel. Although PNC officials agree, they say that the Carter plan was intended to block the start of a prototype fuel reprocessing plant in Tokai north of Tokyo and that it was never carried out.

Several countries have considered incorporating transuranic elements into fuel. France, for example, is looking into separating transuranic elements from high-level waste in its next-generation reprocessing technology. Similarly, Japan has poured billions of yen into its OMEGA project, one aim of which is to develop techniques for separating transuranic elements from highlevel liquid waste. But PNC officials say the present proposal goes beyond OMEGA by incorporating the transuranics directly into the stream for reprocessed fuel.

Apart from the necessary chemical extraction technology, the PNC proposal requires sophisticated robot technology for processing the much more radioactive material into fuel. "This is why the idea may please politicians but it is not at all popular with fuel manufacturers or reactor operators" says Nedderman. But PNC is a semigovernment organization generously funded by the Japanese government that can afford to look into what others see as an uncommercial process.

David Swinbanks

\section{NEWS IN BRIEF}

Washington. More than 350 physicists based in the United States have signed a petition to the Chinese Minister of Justice urging the release of Liu Gang, a 30-yearold graduate student in physics jailed for his pro-democracy activities. The petition, which was sent to Beijing last week, condemns China for "routine torture and humiliation" of inmates at Lingyuan prison, where Liu Gang is jailed, and seeks to free those confined for their democratic beliefs. The petition is sponsored by the American Physical Society and the Committee to End the Chinese Gulag.

T.W.

Washington. The US National Aeronautics and Space Administration (NASA) is once again accepting applications from scientists with small experiments to be conducted on future flights of the space shuttle. The socalled Get Away Special programme has placed 87 payloads on 18 missions in the past ten years for research from universities, industry and domestic and foreign governments. Prices range up to $\$ 27,000$ for a five-cubic-foot, 200-pound payload, although educational institutions can qualify for a substantial discount. To make a reservation or to obtain additional information, contact Robert Tucker of NASA's Office of Space Flight at (202) 4532347.

J.M.

Washington. The White House Office of Science and Technology has created an Intergovernmental Council on Science, Engineering and Technology (InterSET) to improve communications on technical issues between the federal government and state and local authorities. The 10-member panel will be chaired by Allan Bromley, the president's science advisor, and will include present and former public officials with backgrounds in science and engineering. The council, which held its first meeting last week, is intended to make available to more public bodies solutions to a range of technical problems - from siting water reservoirs to identifying people who collect multiple government subsidies.

\section{Japan committed to plutonium at all costs}

Tokyo. Japan will pursue the development of plutonium as an energy source, regardless of cost, because of a desire to end its dependence on outside sources of fuel. That much was made clear last week by an official of the Science and Technology Agency who released details of the annual white paper (policy document) on nuclear energy prepared by the Atomic Energy Commission. Its commitment comes despite the current unfavourable economics for plutonium and concern that it could be diverted into nuclear weapons or released accidentally into the environment.

The white paper takes a broad look at nuclear power, including the dismantling of nuclear weapons in the former Soviet Union, development of nuclear power stations in Japan and the rest of the world, nuclear fuel recycling and research on fusion. But with Japan preparing to receive more than a ton of weapons-grade plutonium from a nuclear fuel reprocessing plant in France (see Nature 359, 663; 1992), plutonium dominated questioning at the press conference on the annual paper.

Shigeru Maeda, deputy director of the agency's office of atomic energy policy research, said that developing domestic technology to extract plutonium from spent nuclear fuel would give Japan its own "mineral mines" and reduce its dependence on imported fuel. Asked if Japan would use plutonium even if uranium is cheaper, Maeda replied that "if we only base the argument on cost, there is a danger that it may lead to the wrong conclusion...there might be a suspension of the [imported] supply of energy to Japan".

Japan has wanted to achieve energy independence ever since the United States and Britain turned off the taps of imported oil in 1941. The oil crises of the 1970 s and the recent Persian Gulf war have only strengthened the country's resolve. Plutonium, although derived from imported uranium fuel, is "quasi-domestic", according to government officials, because Japan can continue to produce it from spent nuclear fuel even if uranium imports are cut off. At the same time, plentiful worldwide supplies of cheap uranium have undermined attempts in the West to develop plutonium and the fastbreeder reactors that run on the fuel.

Even the Japanese nuclear power industry has begun to voice doubts about the economics of plutonium and fast-breeder reactors. But cheapness and ready availability of imported uranium barely enter into the equation in the minds of Japanese bureaucrats and politicians, who prize above all a reduced dependence on foreign sources of fuel.

David Swinbanks 